Part I. Diseases and problems distinguished by WHO and FAO

Dział I. Choroby i problemy wyróżnione przez WHO i FAO

\title{
TREATMENT RESULTS EVALUATION IN PATIENTS WITH SEVERE SEPSIS, CAUSED BY SEVERE TRAUMATIC BRAIN INJURY AT INTENSIVE CARE UNIT OF TERNOPIL UNIVERSITY HOSPITAL
}

\author{
OCENA WYNIKÓW LECZENIA PACJENTÓW Z CIĘŻKA SEPSA \\ SPOWODOWANA SILNYM URAZOWYM USZKODZENIEM MÓZGU \\ NA ODDZIALE INTENSYWNEJ TERAPII UNIWERSYTECKIEGO SZPITALA \\ W TARNOPOLU
}

\author{
Oleksandr V. Oliynyk ${ }^{1,2(\mathrm{~A}, \mathrm{~B}, \mathrm{C}, \mathrm{E}, \mathrm{E})}$, Bohdana O. Pereviznyk ${ }^{2(\mathrm{E})}$, Anna Ślifirczyk ${ }^{1 \mathrm{(E,F})}$, \\ Oleh V. Yemiashev ${ }^{3(B, C)}$, Nataliya I. Krasiy ${ }^{3(C)}$
}

${ }^{1}$ Pope John Paul II State School of Higher Education in Biała Podlaska, Poland

${ }^{2}$ I.Ya. Horbachevskyi Ternopil State Medical University of Ministry of Public Health, Ukraine

${ }^{3}$ Ternopil University Hospital, Ukraine

Authors' contribution Wkład autorów:

A. Study design/planning zaplanowanie badań

B. Data collection/entry

zebranie danych

C. Data analysis/statistics

dane - analiza i statystyki

D. Data interpretation

interpretacja danych

E. Preparation of manuscript

przygotowanie artykułu

F. Literature analysis/search

wyszukiwanie i analiza literatury

G. Funds collection

zebranie funduszy

\begin{abstract}
Summary
Background. Severe traumatic brain injury stays one of the main reasons of humans' mortality until the age of 40. Ternopil University Hospital delivers medical care to the patients with neurosurgical pathology of Ternopil region, which is comprised of 1107000 citizens.

Material and methods. In this paper we analyzed the treatment results of 301 patients with severe traumatic brain injury (STBI), who were treated at intensive care unit of Ternopil University Hospital during 2013-2014. Microbiological research and evaluation of results were accomplished according to generally accepted principles, based on the Bergey's classification. Results. In 72 patients it was complicated by severe sepsis. The mortality rate in clinic reached $29.7 \%$ in 2013-2014, or equals 1.9 person per 100000 of population. Among the intensive care unit patients with STBI, who had the surgery based on this pathological condition, sepsis developed in $23.9 \%$ of patients. Acute respiratory distress syndrome (ARDS), which complicated sepsis, was successfully cured in $73.3 \%$ of cases, by additional usage of traditional ventilation, kinesiotherapy, oxygen therapy and pulse therapy with glucocortisteroids (GS). $22.2 \%$ of patients obtained acute renal failure, $9.72 \%$ of patients were treated by implementing hemodialysis. Concomitant polytrauma was present in $23.9 \%$ of patients.

Conclusions. Theusageof pulse therapy with glucocortisteroids additionally to traditional mechanical ventilation, kinesiotherapy, and oxygen therapy for the treatment of acute respiratory distress syndrome helps to improve the life expectancy of patients.
\end{abstract}

Keywords: severe sepsis, severe traumatic brain injury, intensive care

\section{Streszczenie}

Wprowadzenie. Silne urazowe uszkodzenie mózgu pozostaje jedną z głównych przyczyn zgonów pacjentów w wieku poniżej 40 lat. Uniwersytecki Szpital w Tarnopolu zapewnia opiekę medyczną pacjentom z patologią neurologiczną z regionu Tarnopola, który zamieszkuje 1,107,000 mieszkańców. Materiał i metody. W tym artykule zostały przeanalizowane wyniki leczenia 301 pacjentów z silnym urazowym uszkodzeniem mózgu (STBI), którzy byli leczenie na oddziale intensywnej terapii w Uniwersyteckim Szpitalu w Tarnopolu w latach 2013-2014. Badania mikrobiologiczne oraz ocena wyników przeprowadzono zgodnie z ogólnie przyjętymi zasadami w obdarciu o klasyfikację Bergeya.

Wyniki. W przypadku 72 pacjentów komplikacją była ciężka sepsa. Śmiertelność zanotowana przez szpital była na poziomie 29.7\% w latach 2013-2014, lub też była równa 1.9 osób na 100,000 populacji. Wśród pacjentów z STBI przebywających na oddziale intensywnej terapii, którzy byli poddani operacji z powodu wystąpienia u nich tego stanu patologicznego sepsa rozwinęła się w przypadku 23,9\% z nich. Zespół ostrej niewydolności oddechowej (ARDS) wraz ze skomplikowaną postacią sepsy został pomyślnie wyleczony w przypadku 73,3\% pacjentów dzięki dodatkowemu użyciu tradycyjnej wentylacji, kinezyterapii, terapii tlenowej oraz leczenia pulsacyjnego glikokortykosteroidami (GS). U 22,2\% pacjentów wystąpiła ostra niewydolność nerek. 9,72\% pacjentów poddano leczeniu za pomocą hemodializą. Towarzyszący uraz mnogi wystąpił w przypadku 23,9\% pacjentów. Wnioski. Użycie leczenia pulsacyjnego glikokortykosteroidami stosowane dodatkowo oprócz tradycyjnej wentylacji mechanicznej, terapii tlenowej w leczeniu zespołu ostrej niewydolności oddechowej pozwala zwiększyć przeżywalność pacjentów.

Słowa kluczowe: ciężka sepsa, silne urazowe uszkodzenie mózgu, intensywna terapia
Tables: 2
Figures: 0

References: 10

Submitted: 12.10 .2015

Accepted: 25.02.2016

Oliynyk OV, Pereviznyk BO, Slifirczyk A, Yemiashev OV, Krasiy NI. Treatment results evaluation in patients with severe sepsis, caused by severe traumatic brain injury at intensive care unit of Ternopil University Hospital. Health Problems of Civilization 2016; 10(1): 5-9. DOI: $10.5114 /$ hpc.2016.58201

Address for correspondence / Adres korespondencyjny: Oleksandr V. Oliynyk, Pope John Paul II State School of Higher Education in Biała Podlaska, Sidorska 102, 21-500 Biała Podlaska, e-mail: alexanderoliynyk8@gmail.com, phone: +4883 3449918

Copyright: (C) 2016 Pope John Paul II State School of Higher Education in Biała Podlaska. This is an Open Access journal, all articles are distributed under the terms of the Creative Commons Attribution-NonCommercial-ShareAlike 4.0 International (CC BY-NC-SA 4.0) License (http://creativecommons.org/licenses/by-nc-sa/4.0/), allowing third parties to copy and redistribute the material in any medium or format and to remix, transform, and build upon the material, provided the original work is properly cited and states its license. 


\section{Background}

Severe traumatic brain injury (STBI) is one of the most prominent mortality and disability causes all over the world. STBI stays one of the main reasons of humans' mortality until the age of 40 [1]. In Great Britain STBI frequency is 1500 people per every 100000 of population. 9 patients out of 100000 of population die because of traumatic brain injury [2-4].

Among the complications of STBI the prominent role is given to severe sepsis. In Germany annual mortality caused by sepsis is over 75000 cases (equals the mortality from myocardial infarction) [6]. In general in Europe it is annually registered up to 500000 sepsis cases. 1 per every 1000 hospitalized patients obtains sepsis [7]. It is similar to the situation in the United States. In the USA sepsis develops in over 750000 people annually, which is 3 cases per 1000 of population per year. Sepsis is the cause of 20\% of intra-hospital mortality, which equals 210000 people annually [7].

The mortality rate in case of severe sepsis is still very high and equals 50-60\% [5]. The highest mortality, which $80-90 \%$, is described in patients with septic shock. All over the world 14 people per minute die because of sepsis and its annual mortality is higher than summarily of HIV, prostate and breast cancer [6].

\section{Material and methods}

We implemented the analysis of treatment results of 72 patients with STBI, followed by severe sepsis, who were treated at intensive care unit of Ternopil University Hospital. It equals $23.9 \%$ of the total amount of patients with STBI, who were treated during 2013-2014 in our hospital. Severe sepsis diagnosis was verified by determining the levels of procalcitonine and C-reactive protein.

Microbiological research and evaluation of results were accomplished according to generally accepted principles $[8,9]$. We used the Bergey's classification. The analysis was implemented using the semiautomatic analyzer «Vitek2». After the primary bacterial culture was allocated, we implemented its identification by using Kirby-Bauer discdiffusion method. The permission for research implementation was given by Bioethics commission of Ternopil State Medical University (protocol №29 from 20.05.2015). All the experimental procedures were followed in accordance with the Helsinki Declaration of 1975.

\section{Results}

All around the worlds STBI patients' mortality equals $80 \%$ [10]. That's why the result of $29.7 \%$ should be considered as an achievement. Among the patients of intensive care unit in Europe and USA sepsis develops in $20-40 \%$ of cases. In our clinic it is $23.9 \%$. We should say that these 72 patients were the most complicated for us to deal with. The received result is also a kind of achievement because in $94.4 \%$ of cases sepsis was gram-negative, while it is known that its mortality is twice higher than from gram-positive [6]. The patients' characteristics are provided at Table 1. The results of microbiological research of 897 isolates are present in Table 2.

Table 1. The characteristics of the patients with STBI, followed by severe sepsis, who were treated at intensive care unit of Ternopil University Hospital during 2013-2014

\begin{tabular}{|l|c|c|}
\hline Values, which characterize patients with STBI and severe sepsis & $\begin{array}{c}\text { Absolute } \\
\text { values }\end{array}$ & $\begin{array}{c}\text { Relative values (\%), relating to corresponding } \\
\text { number of patients with STBI and severe sepsis }\end{array}$ \\
\hline $\begin{array}{l}\text { Total amount of patients with STBI, who had a surgical inter- } \\
\text { vention }\end{array}$ & 301 & \\
\hline $\begin{array}{l}\text { Amount of patients with STBI, who were treated at intensive } \\
\text { care unit }\end{array}$ & 154 & 100.0 \\
\hline $\begin{array}{l}\text { Amount of patients with STBI, followed by severe sepsis, } \\
\text { who were treated at intensive care unit }\end{array}$ & 72 & 29.17 \\
\hline Amount of dead patients with STBI & 21 & 30.56 \\
\hline Amount of dead patients with STBI and severe sepsis & 22 & 40.28 \\
\hline $\begin{array}{l}\text { Amount of patients discharged from hospital with moderate } \\
\text { cognitive dysfunction }\end{array}$ & 29 & 26.3 \\
\hline Concomitant polytrauma & 19 & 22.2 \\
\hline Acute renal failure & 16 & 9.72 \\
\hline Dialysis therapy & 7 & 20.83 \\
\hline Acute respiratory distress syndrome (ARDS) & 15 & 25.0 \\
\hline Ventilator-associated pneumonia & 18 & \\
\hline
\end{tabular}




\begin{tabular}{|l|c|c|}
\hline Amount of patients, who had the mechanical ventilation & 72 & 100.0 \\
\hline $\begin{array}{l}\text { Amount of patients with duration of mechanical ventilation } \\
\text { over 30 days }\end{array}$ & 13 & 18.05 \\
\hline Amount of patients with duration of ventilation for 20-30 days & 35 & 48.68 \\
\hline Amount of patients with duration of ventilation up to 20 days & 24 & 33.3 \\
\hline Amount of patients who had hemosorbtion or plasmosorbtion & 36 & 50.0 \\
\hline Total amount of hemosorbtion and plasmosorbtion procedures & 126 & 94.4 \\
\hline Amount of patients with gram-negative flora & 68 & 5.55 \\
\hline The amount of patients with bedsores & 4 & \\
\hline
\end{tabular}

Table 2. Antibiotic resistance of infectious agents at intensive care unit during 2013-2014 (897 isolates)

\begin{tabular}{|c|c|c|c|c|c|c|c|c|c|c|c|c|c|c|}
\hline $\begin{array}{l}\text { Microogranism } \\
\text { distribution, \% }\end{array}$ & 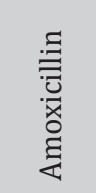 & 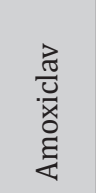 & 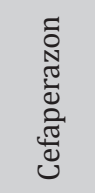 & 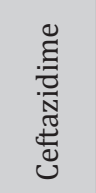 & 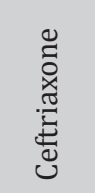 & 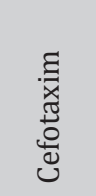 & है & 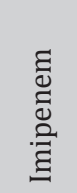 & 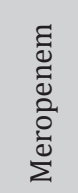 & .ే: & 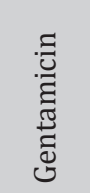 & 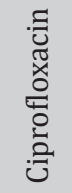 & 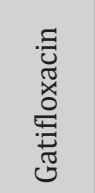 & 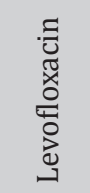 \\
\hline $\begin{array}{l}\text { Escherichia } \\
\text { coli, } \\
6.5 \\
\end{array}$ & 100.0 & 100.0 & 80.0 & 50,7 & 37.5 & 100.0 & 25.0 & 66.7 & 66.7 & 33.3 & 33.3 & 33.3 & 25.0 & 25.0 \\
\hline $\begin{array}{l}\text { Enterobacter } \\
\text { cloacae, } \\
3.3 \\
\end{array}$ & 100.0 & 100.0 & 100.0 & 100,0 & 100.0 & 100.0 & 100.0 & 40.0 & 33.3 & 40.0 & 100.0 & 60.0 & 66.7 & 100.0 \\
\hline $\begin{array}{l}\text { Enterobacter } \\
\text { aerogenes, } \\
11.1\end{array}$ & 100.0 & 100.0 & 100.0 & 87,5 & 100.0 & 100.0 & 100.0 & 40.0 & 62.5 & 76.9 & 71.4 & 84.6 & 100.0 & 66.7 \\
\hline $\begin{array}{l}\text { Acinetobacter } \\
\text { baumannii, } \\
14.3\end{array}$ & 100.0 & 100.0 & 71.4 & 100,0 & 100.0 & 91.4 & 91.4 & 71.4 & 84.6 & 83.3 & 91.7 & 94.1 & 87.5 & 77.8 \\
\hline $\begin{array}{l}\text { Pseudomonas } \\
\text { aeruginosa, } \\
25.5\end{array}$ & 100.0 & 100.0 & 73.5 & 86,7 & 84.6 & 87.5 & 73.5 & 66.7 & 58.3 & 60.0 & 57.9 & 81.0 & 91.7 & 87.5 \\
\hline $\begin{array}{l}\text { Klebsiela } \\
\text { pneumonie, } \\
31.4 \\
\end{array}$ & 100.0 & 100.0 & 97.2 & 100,0 & 100.0 & 100.0 & 97.1 & 53.0 & 54.0 & 65.7 & 88.9 & 92.9 & 83.3 & 88.9 \\
\hline $\begin{array}{l}\text { Staphylococcus } \\
\text { aureus, } \\
7.8\end{array}$ & 30.0 & 30.0 & 00.0 & 00.0 & 50,0 & & & 66.7 & & & 00.0 & 00.0 & & 50.0 \\
\hline
\end{tabular}

\section{Discussion}

Treatment strategy equaled to the Guidelines for the Management of STBI, created by American Association of Neurological Surgeons (2007), which was modified based on our conditions [4].

We used the following principles of intensive therapy for the patients with STBI, followed by severe sepsis.

1. The elevation of the head end of the bed at 30 degrees provides an adequate cerebral perfusion; average blood pressure should be stable at the level of no less than $90-95 \mathrm{~mm} \mathrm{Hg}$ (systolic blood pressure should be no less than $130 \mathrm{~mm} \mathrm{Hg}$ ). The infusion of vasopressors should be carried in order to keep blood pressure stable.

2. The compliance of adequate mechanical ventilation should be provided. Patients' staying on spontaneous breathing only in cases when the state of consciousness equals no less than 12 points according to Glasgow Coma Scale. In patients with less than 12 points (sopor-coma) the tracheal intubation should be managed. Any doubts of the need of intubation should be treated as indication for providing this manipulation. Patients with 9 or less points of Glasgow scale should have mechanical ventilation in mandatory mode. The episodes of patients' desynchronization with the respirator should be managed by the selection of right ventilation mode, because it can lead to the increase of intracranial pressure. It is obligatory to prevent the hypoxia, which can intensify brain edema. Early tracheostomy is provided to the $3^{\text {rd }}$ day of staying in the intensive care unit in case of prognostication of prolonged ventilation. Analgosedation is delivered with the usage of narcotic analgesics (infusion pump of fentatyl), and following sibazone, diprofol, sodium tiopenthal. Mandatory ventilation modes are used only when other ones are ineffective and in case of Glasgow scale 
point of 9 and higher. It is also obligatory to anticipate hyperventilation in order to prevent hypocapnia. While implementing mechanical ventilation we should be striving for normoventilation and normocapnia. The best ventilation modes to use are the ones that cause the minimal elevation of intrathoracic pressure. The optimal oxygen content of the breathing mixture is $40 \%$. In case of worsening of neurological status because of dislocation of the brain, the oxygen content should be increased up to $100 \%$.

3. It is needed to prevent the influence of following factors, which decrease the cerebral perfusion and oxygenation:

- sharp increase of intrathoracic pressure;

- hypo- and hyperosmolarity;

- hypo- and hypercapnia;

- hypo- and hyperglycemia;

- hyperthermia.

4. Infusion therapy should be delivered in first hours of staying at intensive care unit and in volumes to correct hypovolemia and water-electrolyte imbalance. We prefer the infusions of crystalloids, except for $5 \%$ glucose solution. We try to manage normal osmolarity, glycemia, potassemia, sodiemia. Usually, it is possible to eliminate hypovolemia in first 12 hours after injury. Despite of surgical intervention or its absence, the most important issue to deal with is brain edema. After correction of hypovolemia it is not needed to hyperhydrate the patient and then give diuretics in order to deal with brain edema. The better option is to give the bigger amount of fluid, except for the volume that is needed for IV infusion of antibiotics, per os. The fluid balance should be corrected by check-up on diuresis and cental venous pressure.

5. From the 1st day of patient's staying it is needed to make the attempts of drug stimulation of gastrointestinal tract with the usage of enteral nutrition for lowering the expectancy of gastro-intestinal insufficiency development. Enteral administration of fluids and food usually start from 2-3 day. Patients should receive a balanced mix of 2000-4000 calories and 1,5-2 grams of protein per day.

6. For hyperglycemia correction the insulin infusion with the usage of infusomat is needed. Daily doses mixtures are comprised of average $200 \mathrm{~g}$ of sugar. As the background for probable hyperglycemia it needs the increase in insulin dose. We use the enteral and parenteral mixtures for diabetics as it helps to decrease the need in insulin. It also led to the fact that $94.5 \%$ of our patients didn't obtain bedsores.

7. The prescription of adequate antibiotic therapy is also an important issue. As the majority of microorganisms in our department are gram-negative, the drugs of choice are meropenem, tienam, amikacin, colomycin. Over the last 3 years, we observed the increase of sensitivity of microflora to chloramphenicol, streptomycin, gentamicin (5 years ago it was $100 \%$ resistance).

8. $20.8 \%$ of patients obtained ARDS as the complication of sepsis. In treatment protocol with the level of evidence A there are mechanical ventilation, oxygen therapy, kinesiotherapy. The antibiotic and corticosteroids therapy equals to level C. Despite of this fact, we have done the pulse therapy with corticosteroids to all of our patients, who were diagnosed with this complication during first 2-3 days after its development. We also provided the continued mechanical ventilation (no less than 2 weeks) with the privilege of possible mandatory modes. 11 patients (15.3\% of total amount, and $73.3 \%$ of patients with ARDS) survived.

9. In order to deal with hyperthermia we used all possible groups of drugs: non-steroidal and steroidal antiinflammatory, non-narcotic analgesics, mechanical methods of cooling.

10. The best way to deal with intracranial hypertension is the dosed drainage of cerebrospinal fluid through ventricle catheter.

11. The monitoring of heart rate allows avoiding severe arrhythmias.

\section{Conclusions}

1. Compliance of the Guidelines for the Management of STBI, created by American Association of Neurological Surgeons (2007), significantly helps to improve treatment results in patients with following pathological condition.

2. The usage of pulse therapy with glucocortisteroids additionally to traditional mechanical ventilation, kinesiotherapy, and oxygen therapy for the treatment of ARDS helps to improve the life expectancy of patients.

\section{References:}

1. Schurz M, Sturm D, Richland F. Dual-Route Perspective on Brain Activation in Response to Visual Words: Evidence for a Length by Lexicality Interaction in the Visual Word Form Area (VWFA). Neuroimage 2010; 49(3): 2649-2661. 
2. Albrecht J, Liu X, Baumgarten M. Benefits and risks of anticoagulation resumption following traumatic brain injury. The RESCUE icp study Randomised Evaluation of Surgery with Craniectomy for Uncontrollable Elevation of Intra-Cranial Pressure Addenbrooke's Hospital, Cambridge, CB2 2QQ. UK JAMA Intern Med 2014; 174(8): 1244-51.

3. Jane J, Kim D, Alisa D. Gean Imaging for the Diagnosis and Management of Traumatic Brain Injury. Neurotherapeutics 2011; 8(1): 39-53.

4. Guidelines for the management of severe head injury. Brain trauma foundation American Association of Neurological Surgeons, Joint Section on Neurotrauma and Critical Care: 2007; New York, 106 p.

5. Liu V, Escobar G, Greene J. Hospital Deaths in Patients with Sepsis from 2 Independent Cohorts. JAMA $2014 ; 5$.

6. Yealy D, Kellum J, Juang D. A randomized trial of protocol-based care for early septic shock. N. Engl. J. Med. 2014; 370: 1683-1693.

7. Dellinger R, Levy M, Rhodes A. Surviving Sepsis Campaign: International guidelines for management of severe sepsis and septic shock: 2012. Crit Care Med. 2012; 41: 580-637.

8. Varivoda E, Tonko O, Fisenko E, Levshina N. Microbiological Support for Infection Control in Health Institutions of Minsk. EpiNorth 2009: 10(3):135-138.

9. Murray P, Baron E, Jorgensen J, Landry M, Pfaller M. Susceptibility test methods: dilution and disk diffusion methods. Manual of clinical microbiology. 9th ed. ASM Press, Washington, D.C. 2007: 1152-1172.

10.Поліщук М, Макаров А, Панферов С. Структура поєднаної черепно-мозкової травми у відділенні полі травми міської клінічної лікарні №17 м. Київ. Україна. Здоров’я нації 2010; 4(16): 13-17 (in Ukrainian). 